\title{
Article \\ Component Materials, 3D Digital Restoration, and Documentation of the Imperial Gates from the Wooden Church of Voivodeni, Sălaj County, Romania
}

\author{
Călin Neamțu ${ }^{1, *}$, Ioan Bratu ${ }^{2}$, Constantin Măruțoiu ${ }^{3}$, Victor Constantin Măruțoiu ${ }^{3}$, Olivia Florena Nemeș ${ }^{3}$,

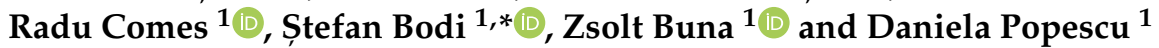 \\ 1 Department of Design Engineering and Robotics, Faculty of Machine Building, \\ Technical University of Cluj-Napoca, 103-105 Muncii Blvd., 400641 Cluj-Napoca, Romania; \\ radu.comes@muri.utcluj.ro (R.C.); zsolt.buna@muri.utcluj.ro (Z.B.); daniela.popescu@muri.utcluj.ro (D.P.) \\ 2 National Institute for R\&D of Isotopic and Molecular Technologies, 67-103 Donat St., \\ 400293 Cluj-Napoca, Romania; ibratu@gmail.com \\ 3 Faculty of Orthodox Theology, "Babeș-Bolyai” University, F/N Episcop Nicolae Ivan St., \\ 400117 Cluj-Napoca, Romania; marutoiu.constantin@ot.ubbcluj.ro (C.M.); \\ marutoiu.victor@ot.ubbcluj.ro (V.C.M.); marutoiu.olivia@ot.ubbcluj.ro (O.F.N.) \\ * Correspondence: calin.neamtu@muri.utcluj.ro (C.N.); stefan.bodi@muri.utcluj.ro (Ș.B.)
}

Citation: Neamțu, C.; Bratu, I.; Măruțoiu, C.; Măruțoiu, V.C.; Nemeș, O.F.; Comes, R.; Bodi, Ș.; Buna, Z.; Popescu, D. Component Materials, 3D Digital Restoration, and Documentation of the Imperial Gates from the Wooden Church of Voivodeni, Sălaj County, Romania. Appl. Sci. 2021, 11, 3422. https://doi.org/10.3390/ app11083422

Academic Editor: Marek Milosz

Received: 15 March 2021

Accepted: 8 April 2021

Published: 11 April 2021

Publisher's Note: MDPI stays neutra with regard to jurisdictional claims in published maps and institutional affiliations.

Copyright: (c) 2021 by the authors. Licensee MDPI, Basel, Switzerland. This article is an open access article distributed under the terms and conditions of the Creative Commons Attribution (CC BY) license (https:/ / creativecommons.org/licenses/by/ $4.0 /)$.
Abstract: The wooden churches from Transylvania, Romania, are a unique and representative cultural heritage asset for rural communities, both in terms of architecture and the style of painting that defines them as monuments of national heritage. These churches are in danger of degradation because rural communities are beginning to abandon them for various motives (e.g., they are too small, are expensive to maintain, or are being replaced by modern churches, built of stone and modern materials). The reason behind their accelerated degradation is that they are covered with shingles that need to be periodically changed and repaired to prevent water from reaching the inner painting layer, a process that is, in many cases, ignored. Imperial gates are the symbol of these churches and separate the nave from the narthex. They are made entirely out of wood and were sculpted and painted manually by skilled craftsmen and still represent the central element of these churches, in terms of art and aesthetics. The digital preservation of these heritage assets is an interdisciplinary undertaking, which begins with the physico-chemical analysis of the pigments in the painting layer, continues with three-dimensional (3D) digitization of the monument and of the objects of interest (such as the imperial gates), and finishes with a digital restoration of these monuments and artefacts. This paper presents a working methodology, successfully applied in digitizing and digitally restoring imperial gates from wooden churches in Transylvania, namely from the wooden church of Voivodeni, Sălaj County, Romania (Transylvania region). X-ray fluorescence and FTIR spectroscopy were used to determine the pigments in the painting layer of these artefacts, and after they were identified, they were synthesized in laboratory conditions. The resulting color was digitized and used for digitally restoring the artefact(s) to its (their) pristine condition. To popularize these cultural heritage assets, the authors make use of virtual reality to mediate the interaction between the general public and heritage objects in their current state of preservation, in a digital environment. Moreover, to showcase how these heritage objects were degraded over time, a digitally restored version of the artefact in pristine condition is presented alongside a version in its current state (as is, digitized, but not yet digitally restored).

Keywords: Fourier-transform IR spectroscopy; X-ray fluorescence spectroscopy; digital restoration of cultural heritage; digital preservation of imperial gates; spruce fir wood; painting materials; 3D scanning 


\section{Introduction}

The central element of this paper is an interdisciplinary methodology, which employs state of the art tools, instruments, techniques, and equipment, found suitable by the authors, for capitalizing on a heritage asset (namely, the wooden church of Voivodeni, Sălaj County, Romania, (Figure 1), and the imperial gates from within (illustrated in Figure 2), through digital restoration/conservation and promotion to a wider audience.

In this regard, in the specialty literature we find a series of examples that use various digital technologies for the digital restoration and conservation of various heritage sites, such as: city centers [1], castles, or other monuments [2]. Furthermore, for studying painted artefacts, various techniques are used, such as: energy dispersive X-ray spectroscopy (EDX), polarized light microscopy (PLM), X-ray diffraction (XRD), micro-Raman spectroscopy (m-RS), Fourier-transform infrared spectroscopy (FTIR) and pyrolysis-gas chromatographymass spectrometry (Py-GC/MS) [3]; in this field, the texture obtained by painters when using various brushes and painting techniques, is also studied [4].

This paper focuses on the "Holy Archangels Michael and Gabriel" wooden church from Voivodeni (Figure 1), which is situated on a hill nearby the village, as tradition dictated, and was constructed from dovetail joined wooden beams. The roof has steep angles, and the watchtower is placed on the roof ridge with the spire that surpasses the height of the walls. Inside the church lies an inscription documenting the year when construction started: "It was appointed for the church to be built up from the meadows in the year 1820. And it was built at the expense of the village, parish priest being Colciar Stefan with his priest son Gheorghe Stefan, and the curator was Elci Ioan. And the holy church was finished in the year 1822". The painter was the priest Iosif Perșe from Elciu, who painted this church and the imperial gates from within in the year 1832 [5-9].

The Four Evangelists are depicted on the two imperial wooden gates (Figure 2). Tradition assigned a symbol to each of them. Therefore, Saint Matthew is depicted together with a man (angel), Saint Marc is depicted together with a lion, Saint Luke is depicted together with a calf, and Saint John is joined by an eagle. The painting was deteriorated and needed immediate preservation and restoration.

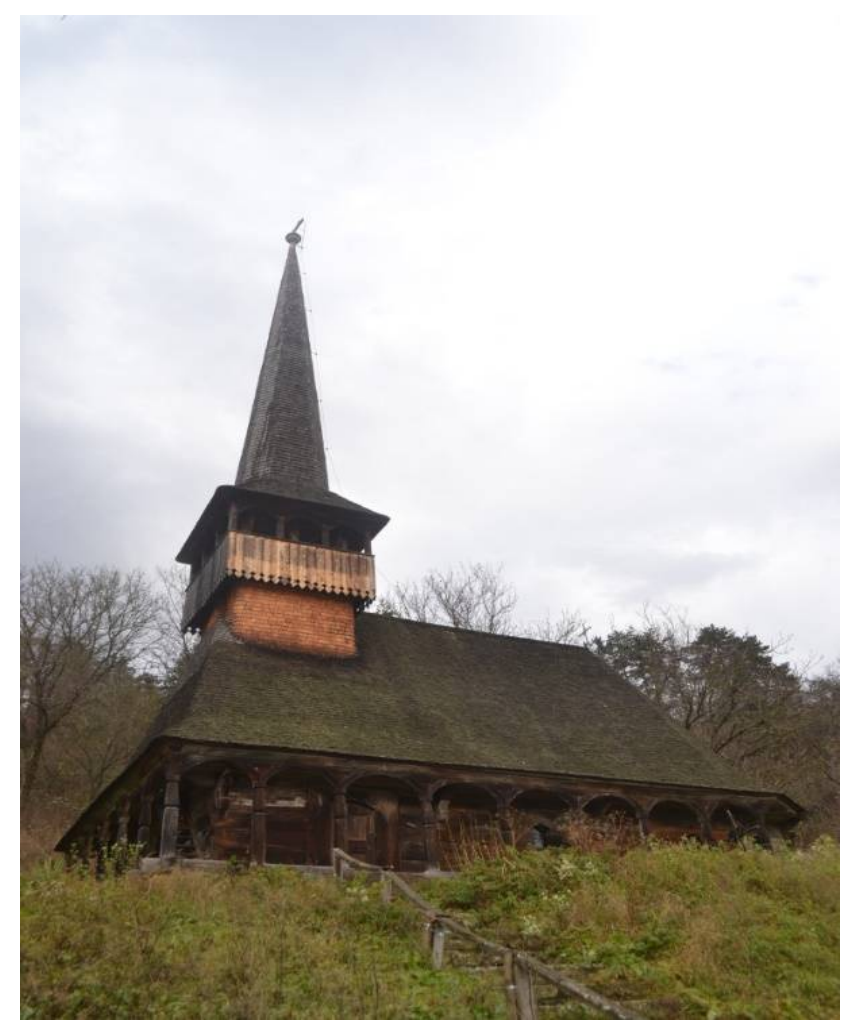

Figure 1. The wooden church of Voivodeni, Sălaj County, Romania. 
The investigation of the component materials (support materials and the painting layer) was completed through XRF and FTIR spectroscopic methods [10-16]. The sampling points for XRF and FTIR spectroscopy investigations are presented in Figure 2.

By employing such physico-chemical methods of investigation, the pigments used in the construction phase are identified and documented, because they represent the starting point in the classic restoration operations of any historical monument.

Furthermore, in order to contribute to the viability of the investigated monument, the authors propose a method of disseminating the results based on cutting edge technologies (namely, augmented and virtual reality-AR/VR). The popularization of this and other such monuments, based on this way of dissemination, may contribute to their reintroduction into religious and cultural tourism circuits, which, in term, would allow the collection and attraction of funds necessary for their maintenance and restoration (self-sustainment).

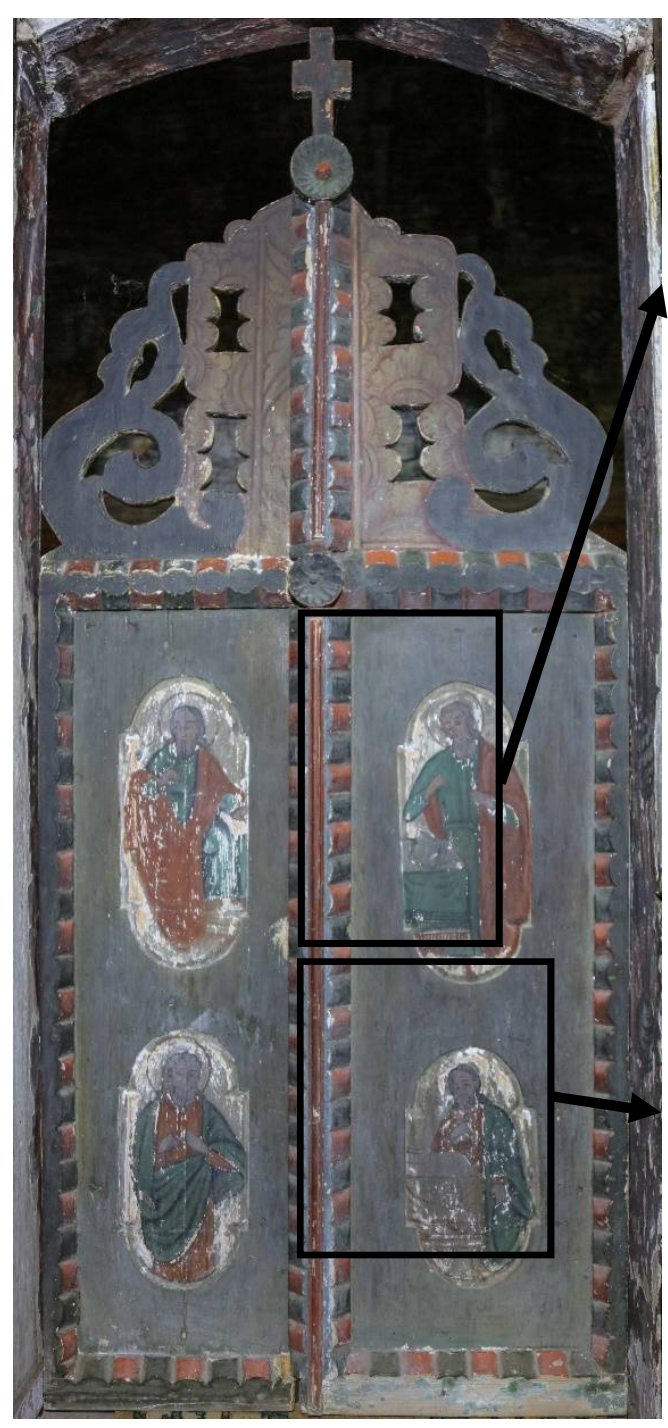

(a)

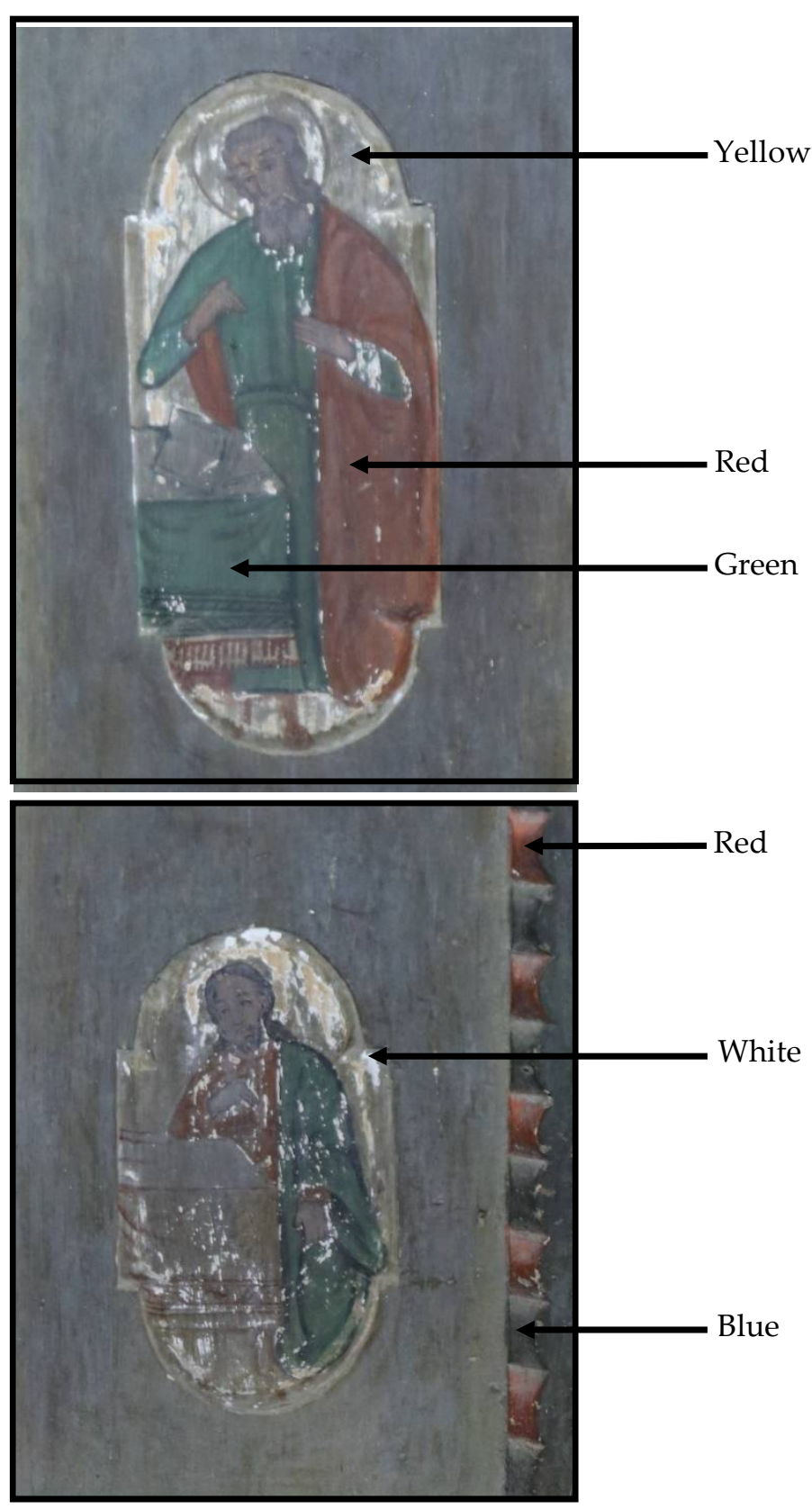

(b)

Figure 2. The Imperial Gates of Voivodeni wooden church (a) and the indication of the sampling points (b). 


\section{Materials and Methods}

The methodology (presented in Figure 3) for carrying out the tasks mentioned above (documentation, restoration, digital preservation, and dissemination) has been validated on several types of artefacts and cultural heritage objects, originating from the church, and it begins with the documentation from an artistic and historical point of view $[15,17]$.

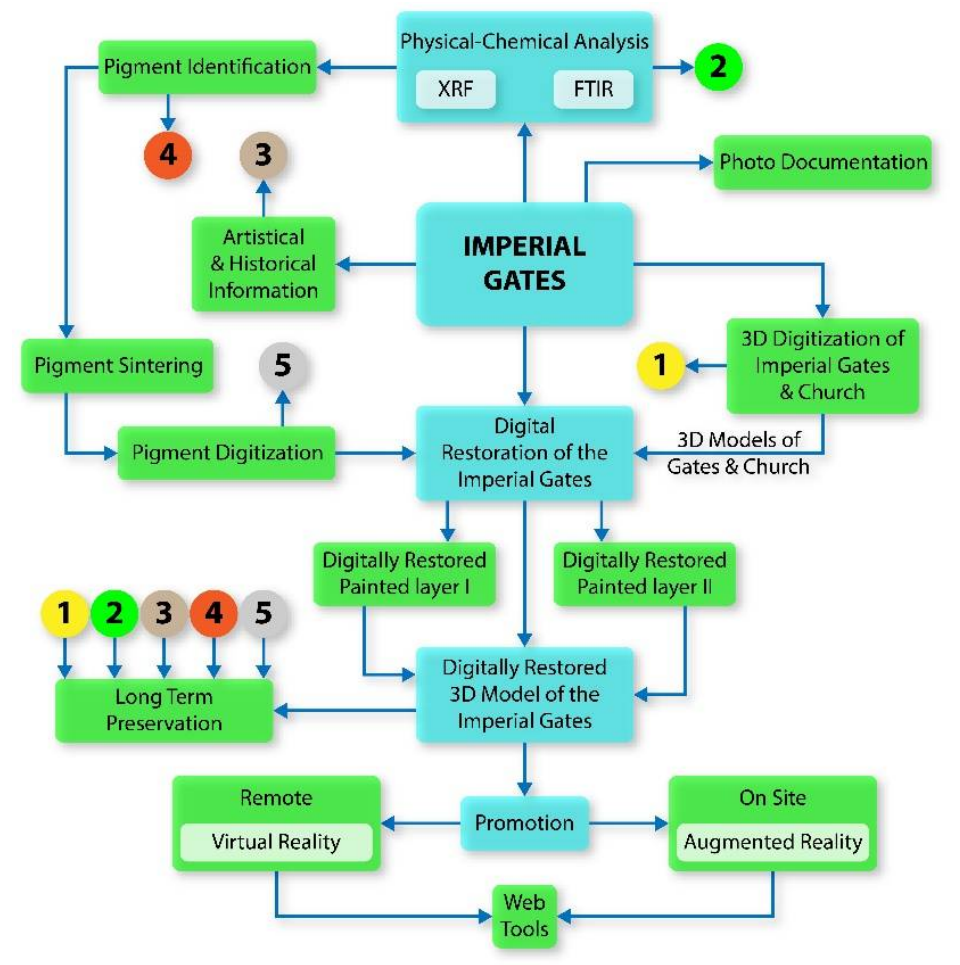

Figure 3. Methodology.

In the first part of the methodology, the artistic and historical documentation is made by art historians and aims to certify the heritage value of the investigated monument. This is completed by using bibliographic, online, and on-site sources.

The second stage consists of the photographic documentation of the monument; in this stage it is pursued the state-of-the-art documentation and conservation of the monument. Overview and detail high resolution photos are taken, in both visible and invisible spectrum (IR or UV), and primary information is collected for digitizing the monument.

The three-dimensional (3D) digitization of the monument can be carried out either by photogrammetry or 3D scanning, depending on required resolution, allotted time for scanning, level of detail, etc. The textured 3D model should present the current state of conservation as accurately as possible in order to document possible future restoration interventions.

The physico-chemical analyzes of the paint layer and the support materials should identify the composition of the pigments and help to identify the problems in the painting's support: pests, fungi, etc.

The identification of the pigments and their synthesis in the laboratory will determine the possible restoration operations, thus, it will be possible to choose compatible materials and it will be possible to study the effect of the current materials used in the restoration of the painting layer. After the pigment compositions are obtained, they can be digitized and documented for the digital preservation of the monument.

The digital restoration operation aims to improve the visual appearance of the monument in a virtual environment and to restore its appearance without any intervention (painted layer I) or its pristine appearance (painted layer 2-see) from the 1820s (when the church was built). 
The digital restoration operation includes information from all stages described above: the scanned model is used to complete and remove the effects of time and other harmful factors on the monument, which is digitally repainted using digitized pigments obtained from the physico-chemical analysis. One can obtain two types of 3D models, one repainted with the initial colors and the other one painted with the current colors.

By going through the stages described so far, a data package is obtained that corresponds to the consolidated digital preservation model, and which contains the following information:

- Historical and artistic analysis;

- Complete photographic documentation of the monument;

- Documentation of the pigments and the state of conservation of the support of the pictorial layer;

- $\quad 3 D$ model of the monument;

- $\quad$ Digitally restored 3D model.

After the completion of the consolidated data package, some elements of it can be further used for the online promotion of the monument both on-site (through AR applications or audio guided tours) and remotely (through VR-type applications-virtual tours).

The main goal of the previously described methodology is to preserve and digitally restore monuments in various stages of degradation. This approach is interdisciplinary, based on techniques from various fields of engineering, and is presented as follows.

\subsection{X-ray Fluorescence}

Non-destructive $X$-ray fluorescence elemental analysis (XRF) was performed with a handheld Bruker spectrometer (as shown in Figure 4), S1 TITAN series (EDXRF) configured with a Silicon diode PIN detector (SiPIN), Rh target X-ray tube with a maximum voltage of $50 \mathrm{kV}$. The use of this approach is validated in various studies, as well [18-20].

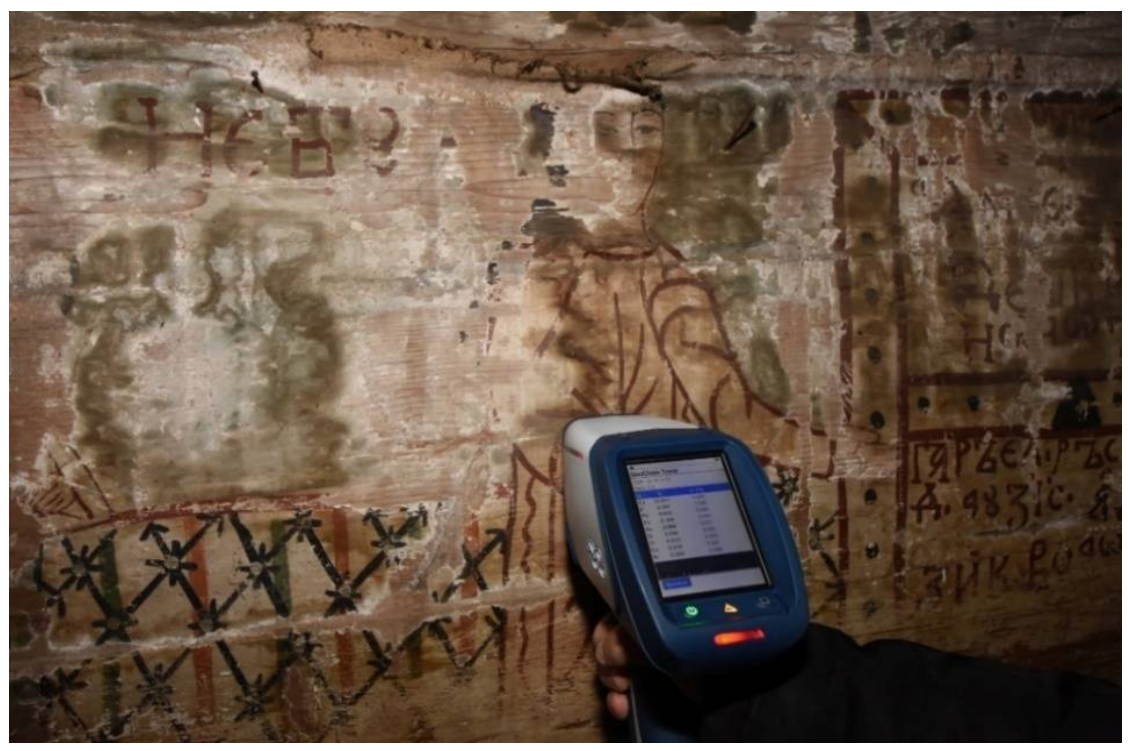

Figure 4. X-ray In-Situ investigation.

\subsection{FTIR Spectroscopy}

Fourier-transform Infrared (FTIR) measurements were performed with a Jasco 6100 spectrometer in the 4000 to $400 \mathrm{~cm}^{-1}$ spectral range with a resolution of $4 \mathrm{~cm}^{-1}$ (256 scans) by employing several $(<1) \mathrm{mg}$ of sample, and $\mathrm{KBr}$ pellet technique was applied. Similar investigations are detailed in other research endeavors, as well [18,21]. The obtained FTIR spectra were processed with the Spectral Analysis and the Origin 8.0 software. The samples were independently collected from the imperial gates and from mural paintings. 


\subsection{Digitization}

The scanning and digitization of the imperial gates are aiming to preserve the conservation status in an electronic format. The $3 \mathrm{D}$ model is further used for various research activities and also for the promotion of these patrimony assets. The digitization was performed using a Creaform Go!SCAN 50 structured light scanner with a $50 \mu \mathrm{m}$ dimensional precision able to acquire textures up to $268 \mathrm{Mpx}$. The digitization operation targeted both the shape and texture of the gates, the data being acquired simultaneously.

The 3D mesh resulted from scanning has approximately 4 million polygons/gate (Figure 5b), which were further transformed to a surface on which the texture (Figure 5a) was remapped. The Imperial Gate surface and the final 3D model are presented in Figure 6.

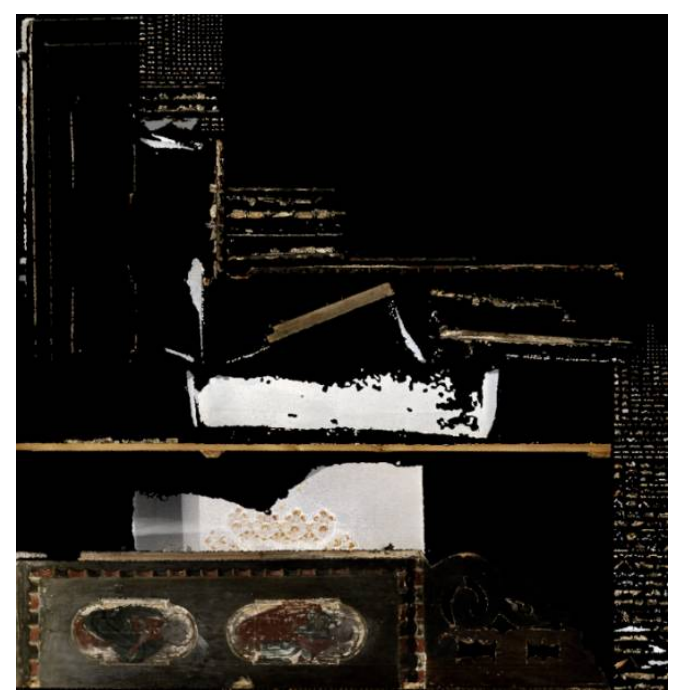

(a)

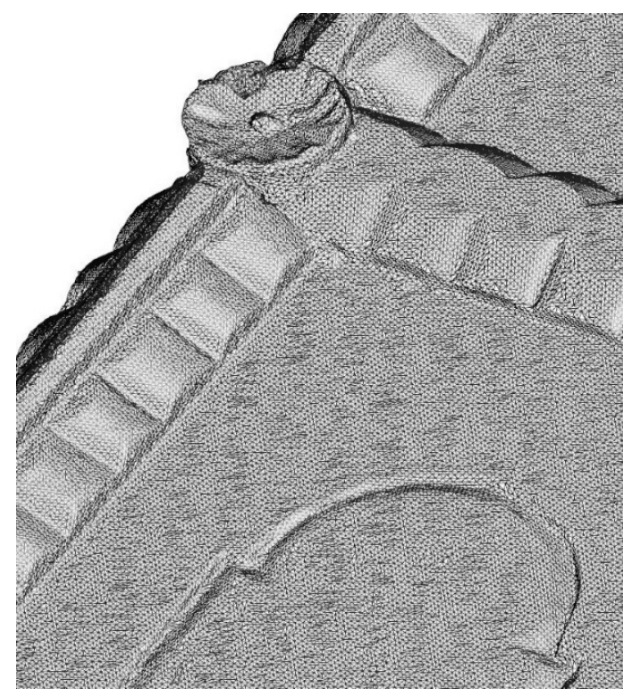

(b)

Figure 5. The texture (a) and the mesh resulted from processing (b).

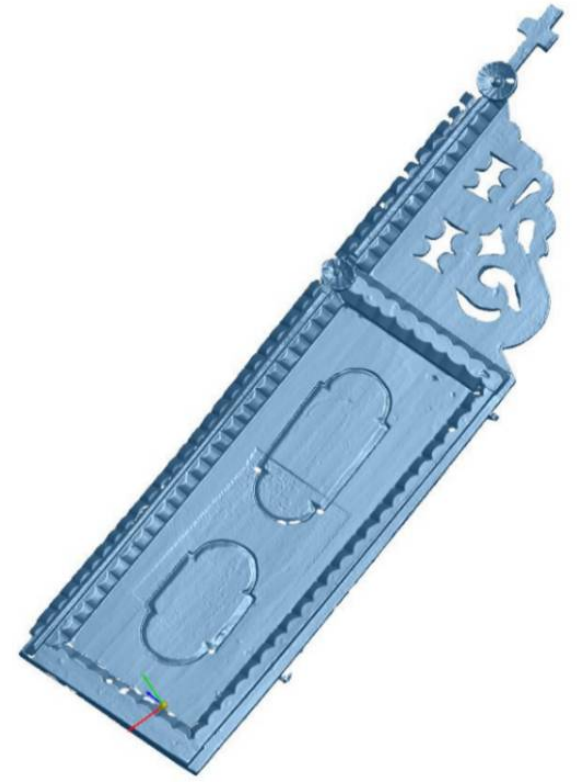

(a)

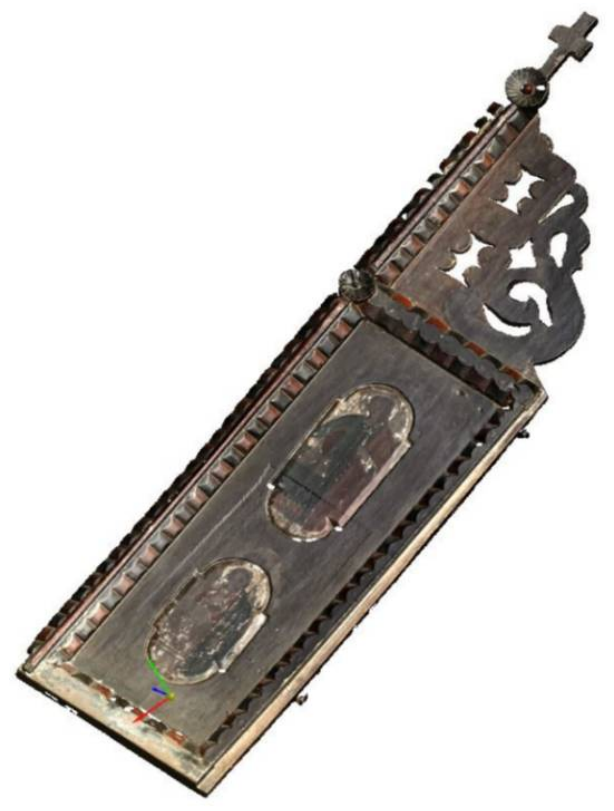

(b)

Figure 6. The Imperial Gate's surface (a) and the final three-dimensional (3D) model (b). 


\section{Results and Discussion}

In the following, the results obtained from deploying the methodology are presented, detailed, and applied by an interdisciplinary team of chemists, theologians, graphic artists, art historians, engineers, and IT specialists. The stages of physico-chemical analysis and digitization of the monument take place in parallel, the completion of the two stages condition the transition to the digital restoration stage.

\subsection{Artistic and Historical Documentation}

An element of these monuments, distinguished by its symbolic significance, are the imperial gates. These are essential components of the iconostasis of the Orthodox Christian churches, with symbolic value for cultural heritage. Byzantine iconography associates with the imperial gates the icon of the Annunciation, as the initial moment of saving humanity, through the symbolic opening of the gates of Heaven by Jesus.

In the Romanian Orthodox tradition, the transcendental passageway is made through three symbolic gates, through three levels of access: the entrance to the precinct, the access gate to the church and the imperial gates, accessible to priests. They separate the altar from the nave. Due to the size of the wooden churches from Transylvania, the imperial gates tend to take on greater importance in the eyes of the faithful.

Following the field study conducted between 2016 and 2019, it was found that the best preserved are those churches that are still functional. The depopulation of rural areas has reduced their number every year. Some of the inactive churches were saved by converting them to open-air village museums. Moreover, valuable artefacts were saved by moving them to these museums.

Of the 68 wooden churches from Sălaj County, Romania (including the three churches that were moved to open-air museums in Sibiu and Cluj-Napoca), only 21 preserve imperial gates, among which is also the church in Voivodeni.

In this stage, a photographic documentation is carried out, in both the visible and invisible spectrum (IR and UV), as shown in Figure 7. The purpose of this stage is to capture the current state of conservation (visible spectrum) and possible interventions or even helpful sketches used during the painting process by folk artists.

The photographic documentation is constituted in a document that will preserve in digital format the current state of conservation of the monument. DSLR cameras (Canon 5DSR - 50Mpx) and a multispectral camera (modified Canon 550-18Mpx) were used to complete this documentation.

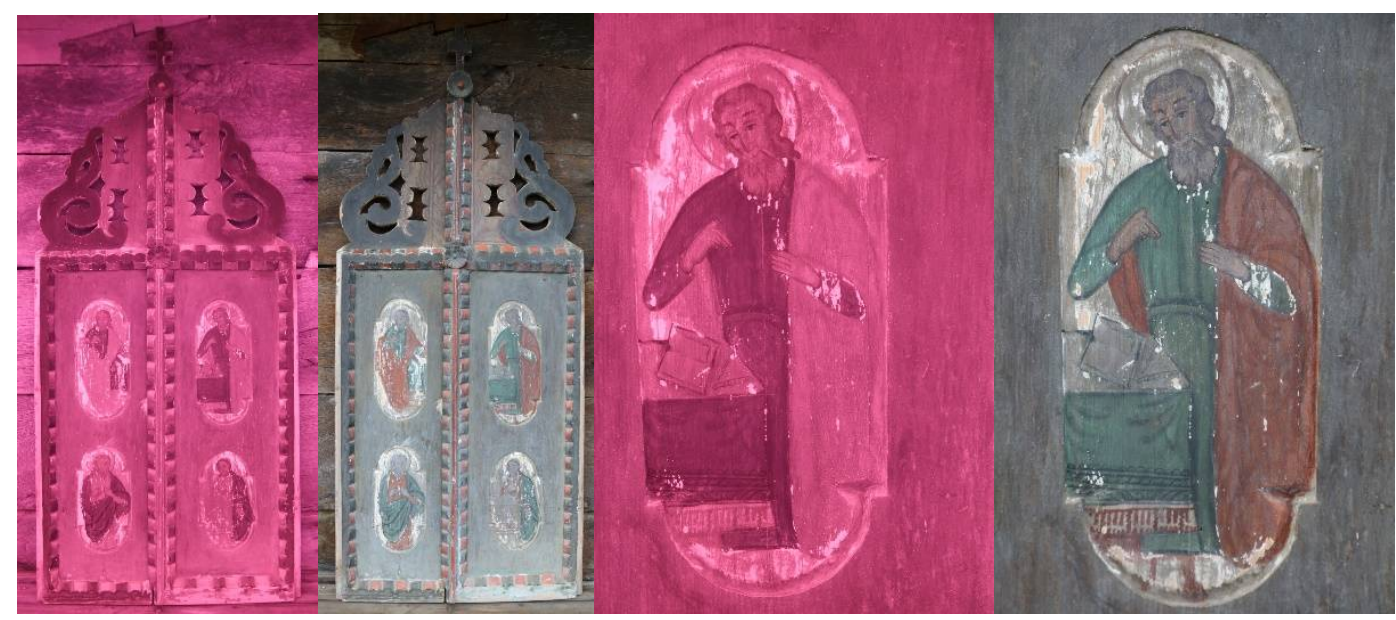

Figure 7. Photographs of Imperial Gates in the visible and IR spectrum.

In Figure 7, the first two images provide an overview of the whole artefact, while the last two showcase a close-up on the top right area. 


\subsection{Digitization}

The wooden church has been scanned using a terrestrial laser scanner ( $\mathrm{Z}+\mathrm{F}$ 5010x) to obtain an accurate colored point cloud of the church's interior and exterior (Figure 8). The vast majority of digital reconstructions are based on 3D models created in various software, but the accuracy of a model generated on a computer, which is based on a layout sketch of the wooden church will not have the required accuracy in terms of geometrical dimensions. Therefore, most digital reconstruction models for cultural heritage assets are based on approximations. By using a state-of-the-art terrestrial laser scanner, it enables a true 1:1 scale digital recreation of the entire church (both interior and exterior) also the part involving the texturizing process is done automatically and accurately, since the scanner is capable to acquire the data as a colored point cloud (XYZRGB file extension).

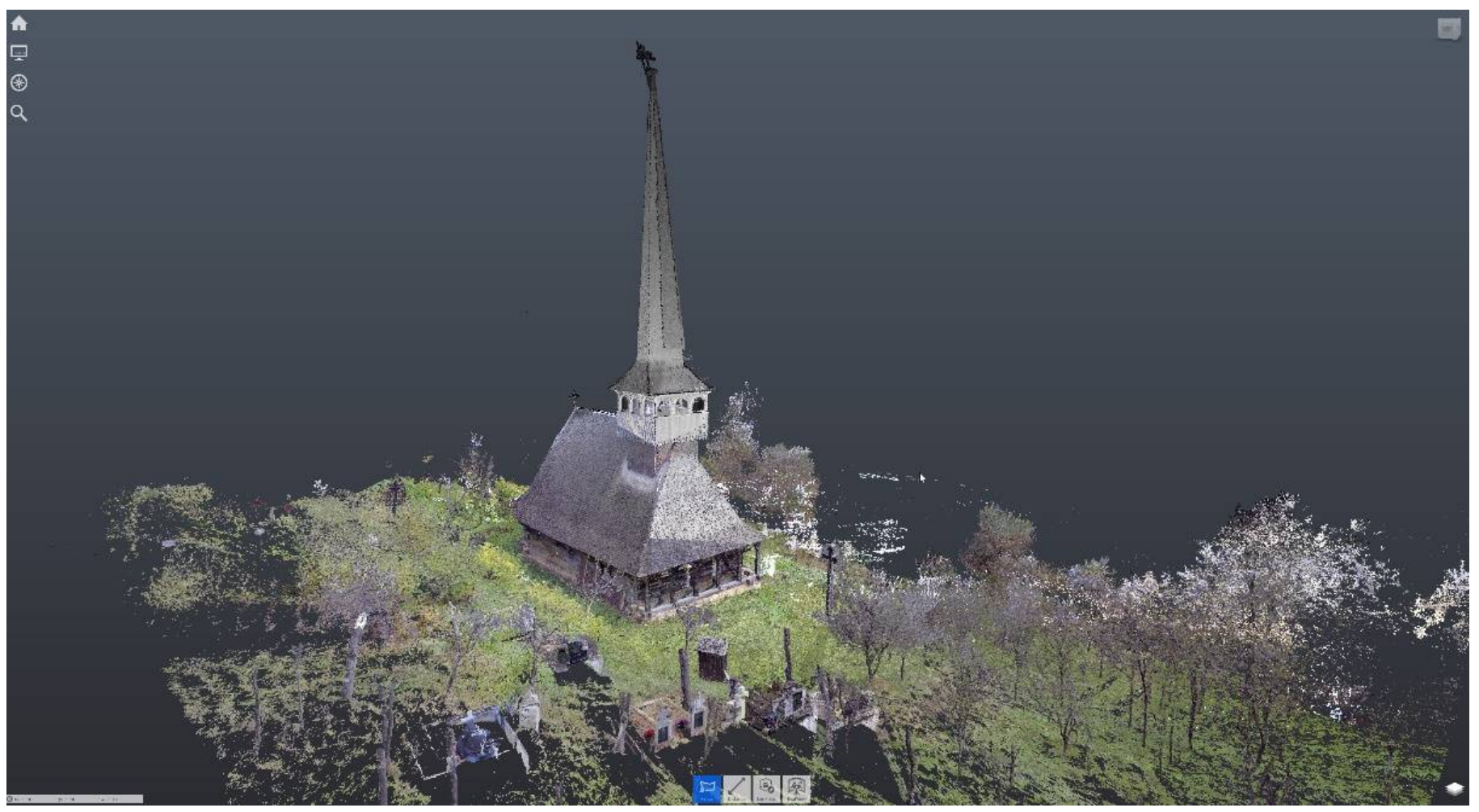

Figure 8. Voivodeni wooden church point cloud and its surroundings, resulted from 3D scanning.

\subsection{XRF}

The purpose of the EDX-XRF spectroscopy was to determine the pigments from the painting materials; they are centralized in Table 1 . The chemical elements of those pigments are detailed in Figure 9a-g.

Table 1. Sampled colors from the imperial gates and identified pigments (based on Figure 9).

\begin{tabular}{ccc}
\hline Color & XRF Spectrum/Figure & Pigment \\
\hline White & Figure $9 \mathrm{a}$ & Lead white \\
Yellow & Figure $9 \mathrm{~b}$ & Orpiment \\
Ground & Figure $9 \mathrm{c}$ & Calcium salt based \\
Red & Figure $9 \mathrm{~d}$ & Red mercury (cinnabar) \\
Blue & Figure $9 \mathrm{e}$ & Azurite \\
Green & Figure $9 \mathrm{f}$ & Malachite \\
Red & Figure $9 \mathrm{~g}$ & Red iron \\
\hline
\end{tabular}




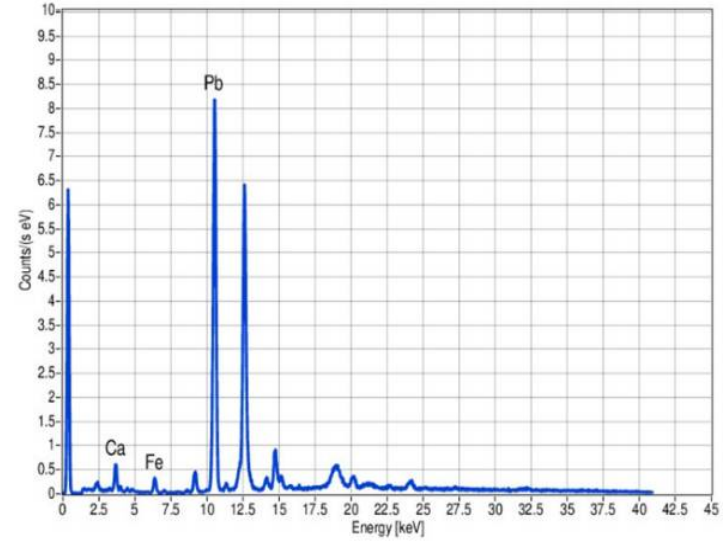

(a)

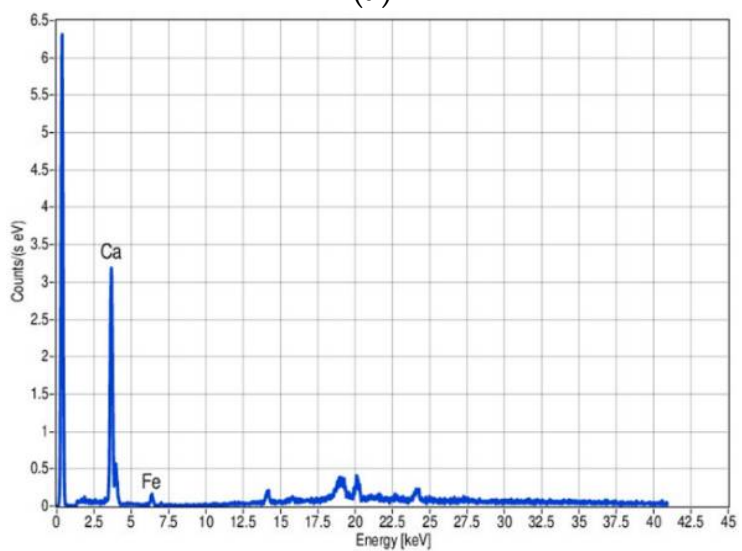

(c)

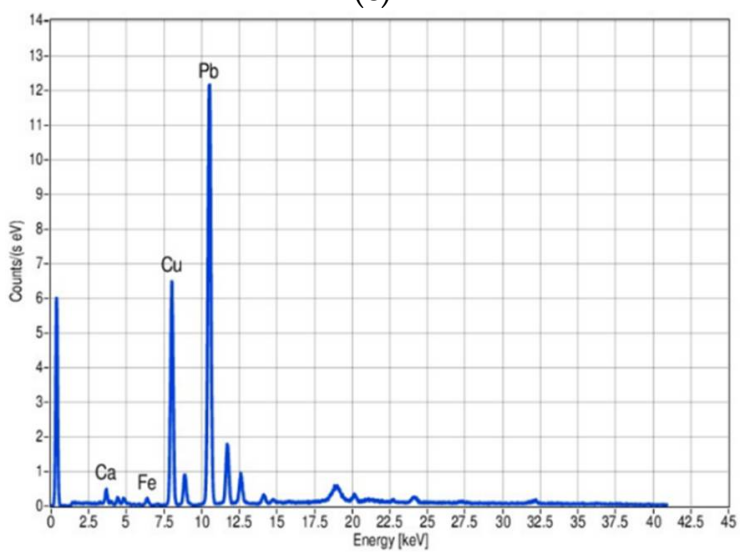

(e)

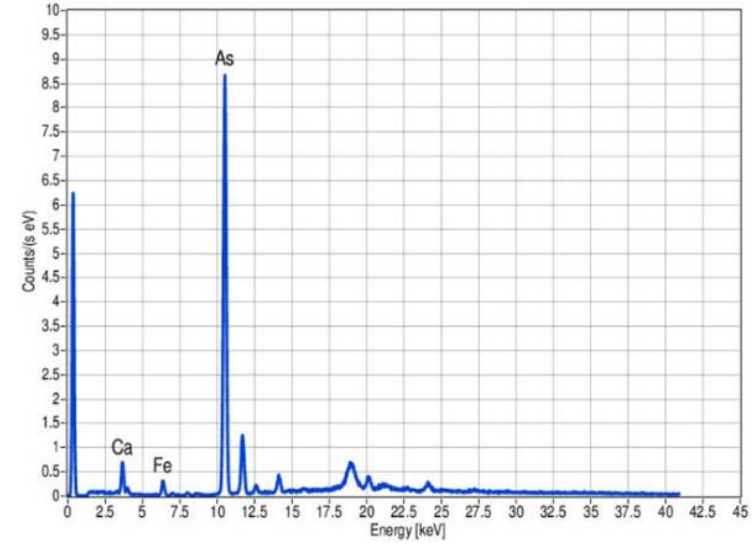

(b)

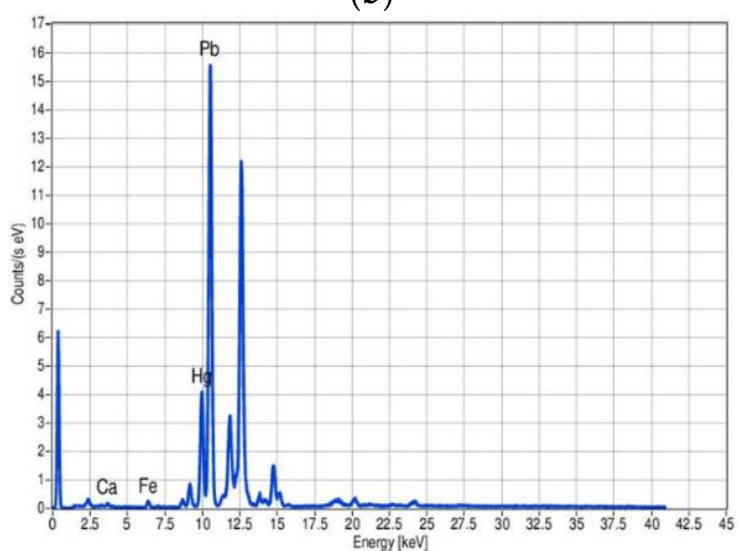

(d)

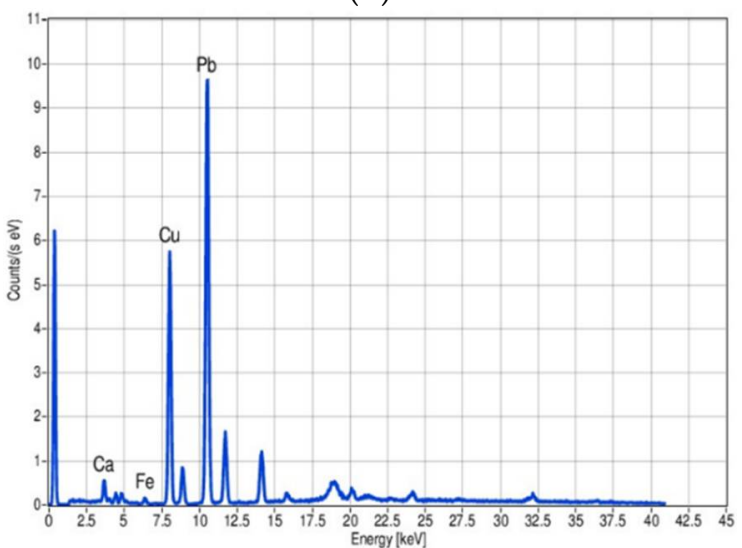

(f)

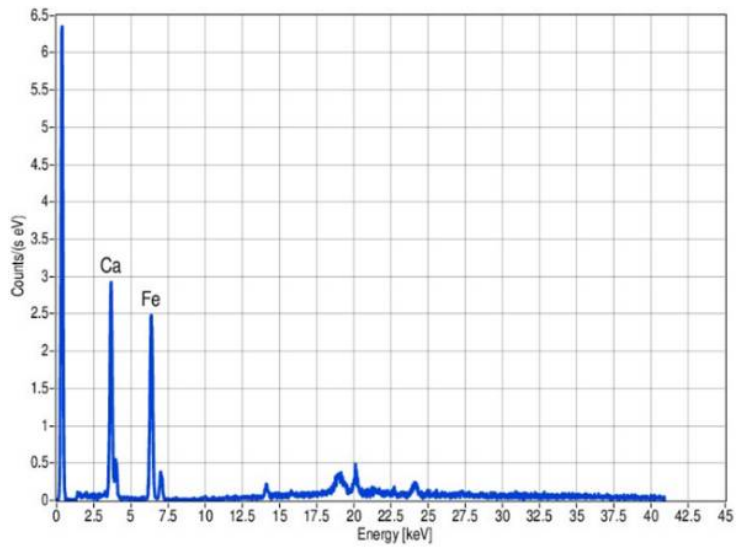

(g)

Figure 9. Chemical elements present in the painting materials. 


\subsection{FTIR Investigation of Imperial Gates Wood}

From the comparison of FTIR spectrum of spruce fir with the FTIR spectrum of imperial gates (IG) wood, of the frame wood, see Figure 10, especially the $1100-900 \mathrm{~cm}^{-1}$ spectral range, spruce fir was identified as being employed for the IG wood and frame.

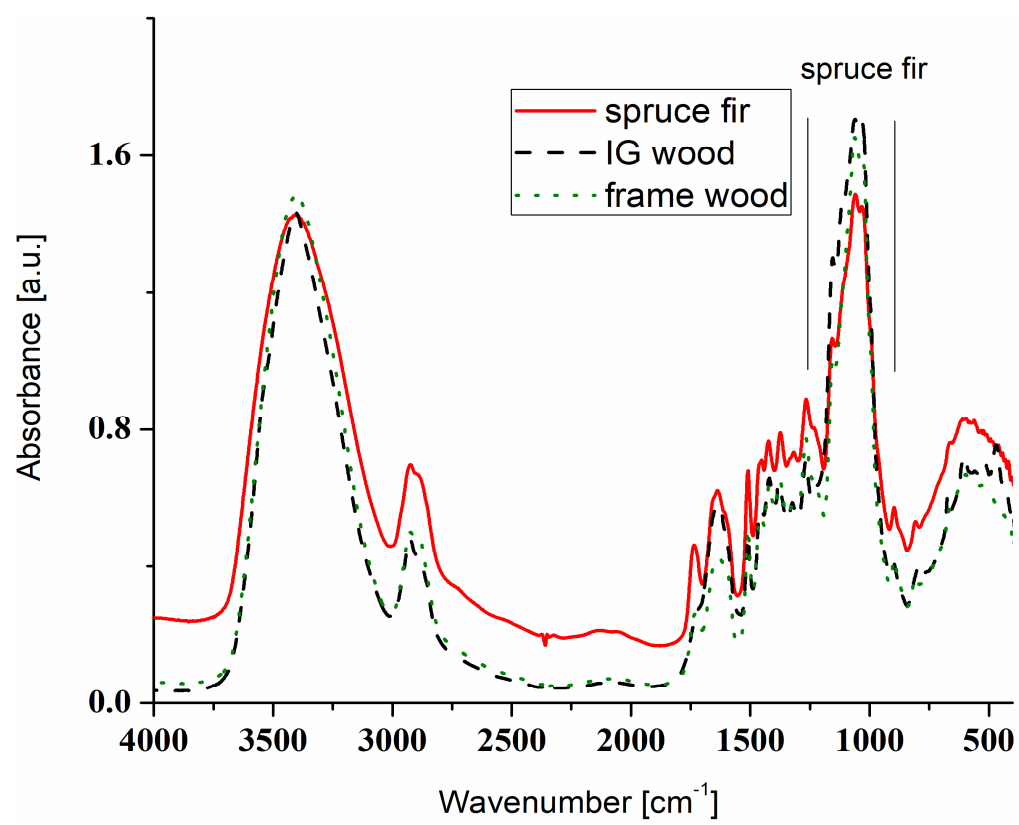

Figure 10. Imperial gates' wood- and frame wood FTIR spectra (as compared to the spruce fir one).

\subsection{Painting Materials}

The green painting material was identified as malachite and gypsum by the characteristic absorptions located at $\sim 3600-3400$ and $1200-1000 \mathrm{~cm}^{-1}$, respectively, see Figure 11 . Yellow painting material was identified by XRF as being orpiment. Egg yolk was identified by its specific absorptions present in the $3000-2800$ and $1800-1500 \mathrm{~cm}^{-1}$ spectral domains (Figure 11). Red and Burgundy painting materials were identified as mixtures of red lead, red iron, and red mercury mixed with gypsum (Figure 12), based on XRF results.

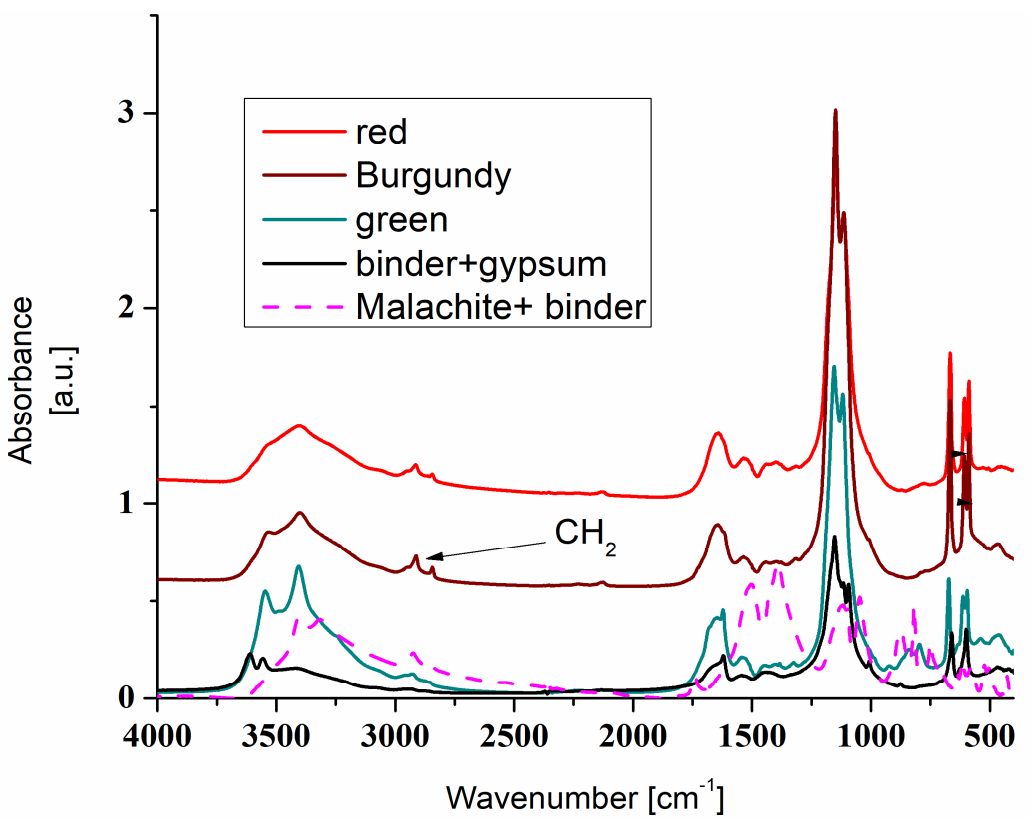

Figure 11. FTIR spectra of the painting materials, 4000 to $400 \mathrm{~cm}^{-1}$ spectral range. 


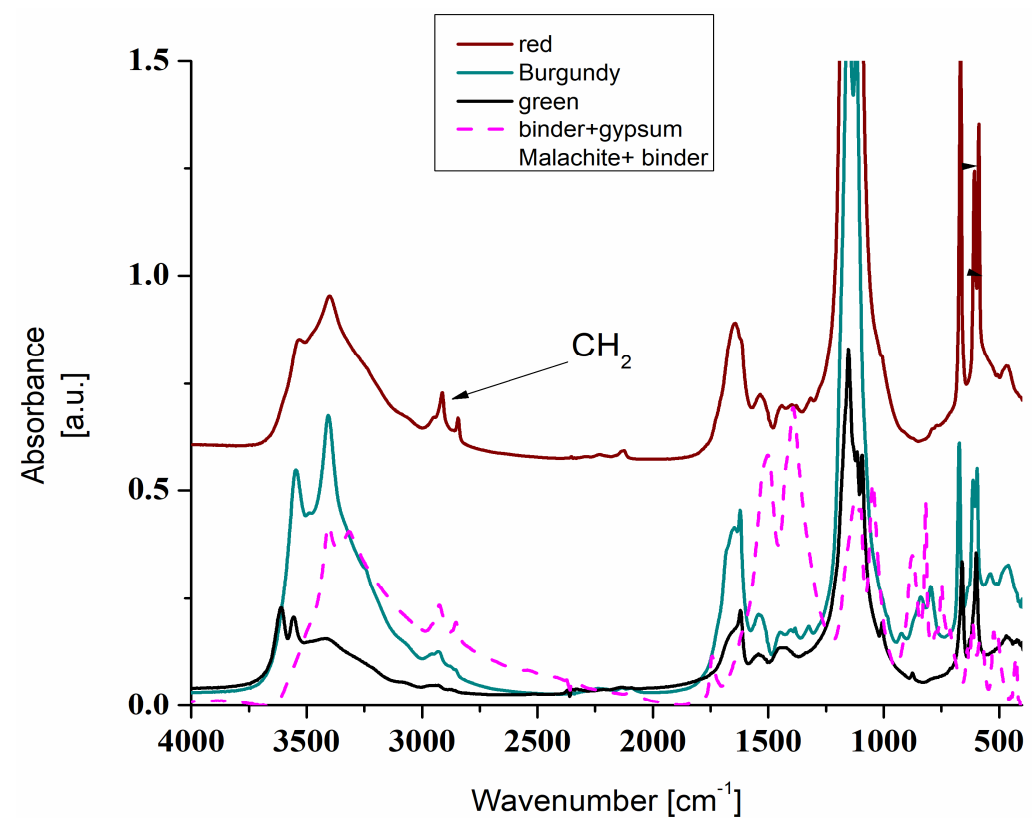

Figure 12. FTIR spectra of the painting materials, 4000 to $400 \mathrm{~cm}^{-1}$ spectral range, Oy extended.

\subsection{Blue Pigment}

Considering the data from XRF and FTIR, (Figures 13 and 14), one can identify traces of azurite or malachite mixed with gypsum, egg yolk, and linen oil in the blue painting material (identified absorptions at 3600-3400 $\mathrm{cm}^{-1}$ for gypsum, $2930 \mathrm{~cm}^{-1}$ for linen oil and egg yolk, $1647 \mathrm{~cm}^{-1}$ egg yolk protein, $\sim 1100-1000$ and $\sim 615-580 \mathrm{~cm}^{-1}$ for gypsum).

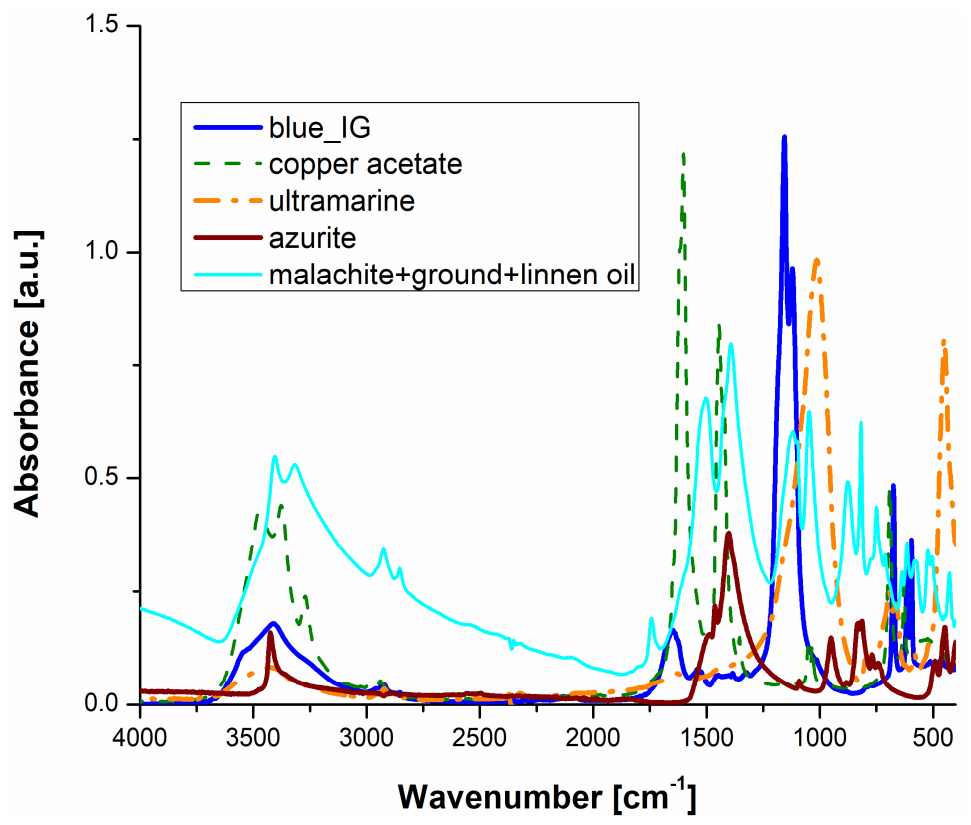

Figure 13. FTIR spectra of various blue and green painting materials, 4000 to $400 \mathrm{~cm}^{-1}$ spectral range. 


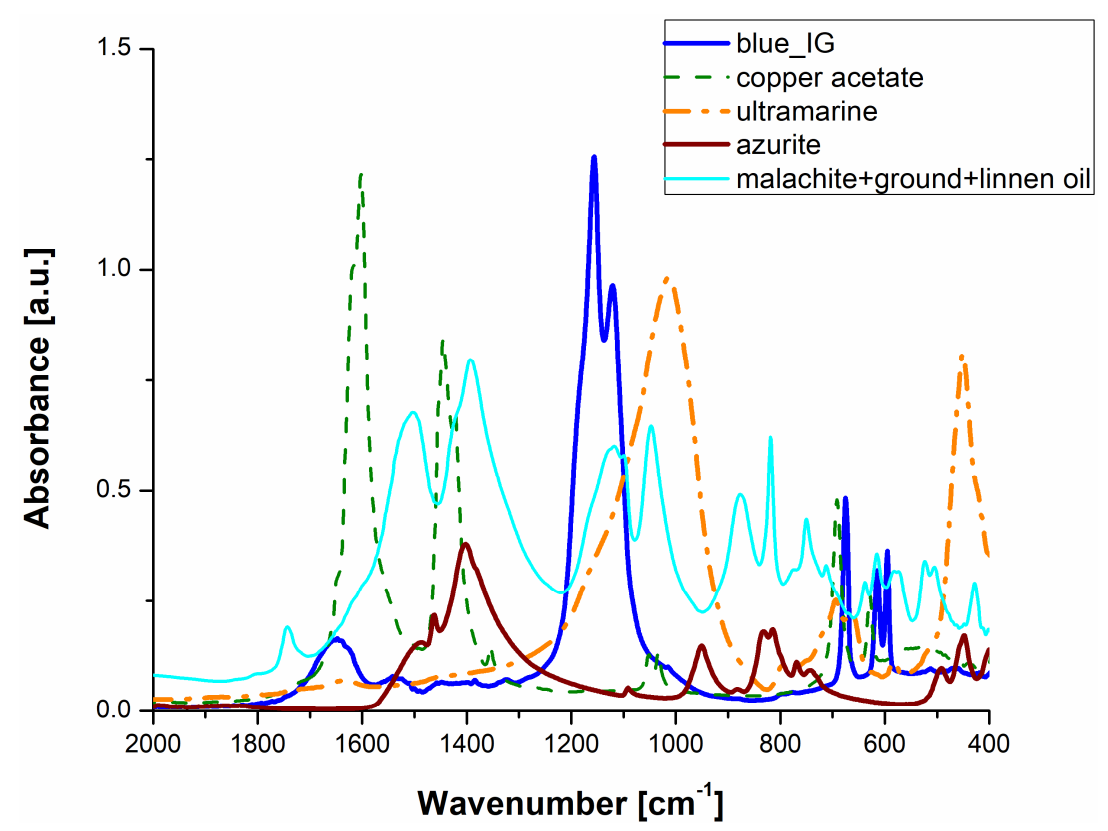

Figure 14. FTIR spectra of various blue and green painting materials, 2000 to $400 \mathrm{~cm}^{-1}$ spectral range, extended Oy axis.

\section{Digital Restauration and VR Environment Integration of Imperial Gates}

Digital conservation of the imperial gates is performed by storing the following data:

- Primary data resulted from scanning and photographing during scanning;

- Detailed 3D model resulted from processing data acquired by scanning without applying data reduction filters or texture compression;

- Optimized 3D model - this is a compressed model resulted from data reduction employing various filtering and compressing operations;

- All the physical and chemical tests performed on the painting layer and wooden support.

The detailed 3D model of the imperial gates (see Figure 6) has approximately 1.8 GB and it is difficult to be accessed by the public, being used mainly for research activities and digital restoration, as shown in [12]. Compressing using various methods [22-25] aims to obtain a simplified 3D model in order for it to be visualized and used on various cross-platform devices.

A virtual application was created in Unity software (version 2020.2.0f1) for the imperial gates, which facilitates their visualization employing HTC Vive. The user can move around these artefacts and can visualize them on a 1:1 scale.

Besides this application, the 3D model is shared on the sketchfab.com platform where users can manipulate the 3D model and stereoscopically visualize the imperial gates using a smartphone and a headset. Using the augmented reality facilities from this platform, the 3D models can be associated with a marker, visualized, and manipulated within the application (Figure 15). The 3D model of the gates can be visualized at https://skfb.ly / 6ZXqx (published: 29 March 2021; accessed: 30 March 2021).

The process of preserving the current situation of the whole wooden church from Voivodeni was one of the most important objectives of the research, but our research is also focused on the potential use of digital image processing to recreate the paintings. As a case study, the digital restauration has been applied on one of the four evangelists, namely, on Saint Marc (upper part of Figures $2 \mathrm{~b}$ and 16). The starting point for this step involves the use of the detailed 3D model, which had the precise 3D geometry as well as the mapped texture acquired using the hand-held Creaform Go!SCAN 50 structured light scanner. To obtain more details for the texture of each Saint, we have used a $50 \mathrm{Mpx}$ full frame DSLR camera to gather a close-up of the painting, which was later merged into a single digital image. The merged high detailed image has been used as the starting point for the digital 
restoration process. To have a better lighting over the painting, the wooden gates were photographed outside in natural sunlight and artificial light, for a better exposure.

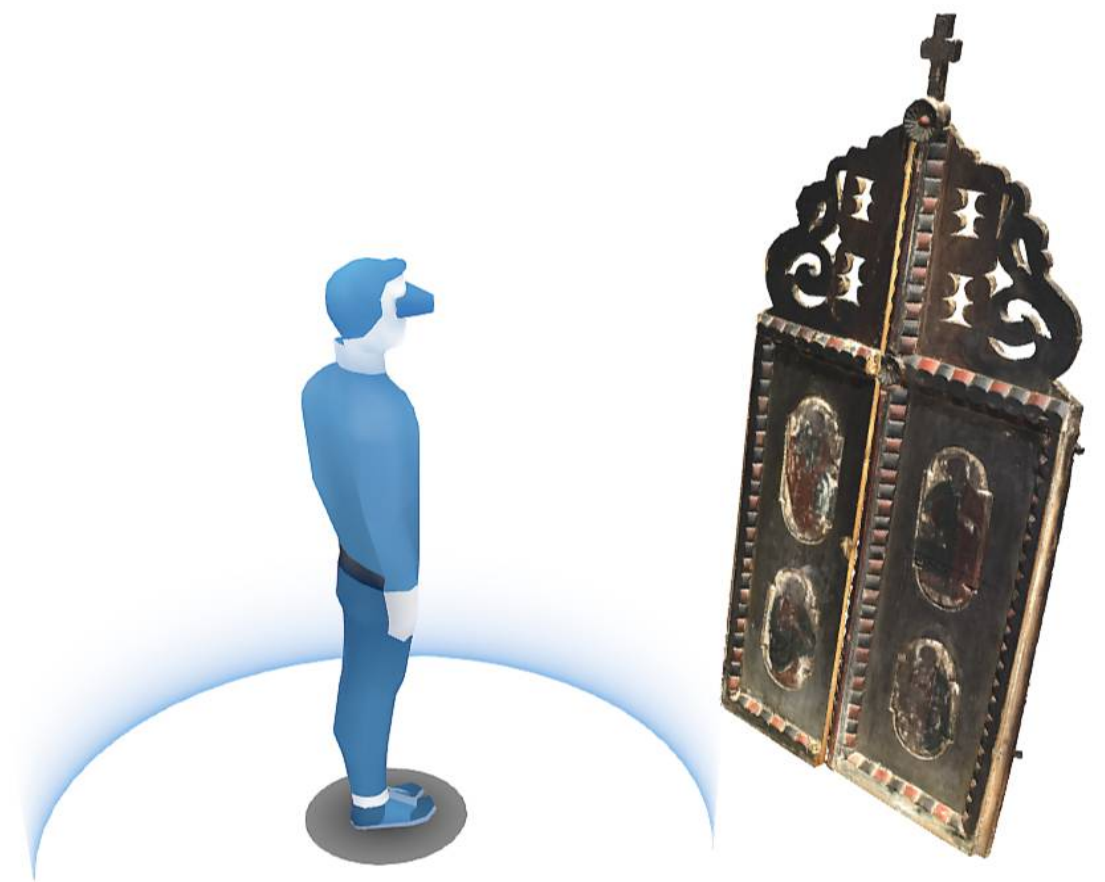

Figure 15. Showcasing the imperial gates using virtual reality.

The proposed digital reconstruction involved adjustment of the color saturation to better illustrate the initial situation and colors of the paintings. A wide variety of digital image manipulation has been applied to recolor the missing areas of the painting and adding details with various brush strokes, the proposed digital reconstruction is highlighted in Figure 16. However, here it must be noted that according to [26] virtual restoration is the process of "using a virtual model to reorder available material remains to visually recreate something that existed in the past. Thus, virtual restoration includes virtual anastylosis", which in turn "involves restructuring existing but dismembered parts in a virtual model". Moreover, because these techniques are deployed in the digital/virtual environment they do not interfere with the materiality of the original artwork, thus virtual restoration does not contravene with well-established principles of physical restoration, such as compatibility, reversibility, or minimal intervention $[26,27]$. Finally, the digitally restored model does not claim to have the same artistic value as the original, its purpose is to illustrate a probable variant of the original artwork, without the action of degrading factors upon it [28,29].

The proposed digital restoration has then been projected on the 3D model obtained using the 3D handheld structured light scanner. To generate a proposed digital restauration the whole right side of the imperial gate has also been recolored using the colors from the chromatic pallet of the digital image acquired by the structured light scanner. For obtaining the image from the right side of Figure 16, the colors used in the repainting process are obtained in laboratory conditions, based on the pigments identified as presented in Section 3.3, centralized in Table 1. By doing so, one can assume that the artefact is colored as its "pristine condition" - before it was affected by degrading (external) factors. The result of the recolored right side of the imperial gate is presented in the figure below, directly in a 3D texturing software (Substance Painter) that enables UV unwrapping and texturing.

In Figure 17, the 3D model and its material are presented, used for texturing purposes, in an unwrapped format; for the texture, a custom physically-based rendering (PBR)-type material was created, capable of reacting with the conditions from the virtual environment 
(lighting, shadows, reflections, etc.) and the mapping mode is "normal mapping", which is a technology of changing a normal pixel based on the chorochromatic map of normals, in which changing data are saved as texels. In this method, three texture channels are used on the map and, thanks to them, it has greater accuracy.
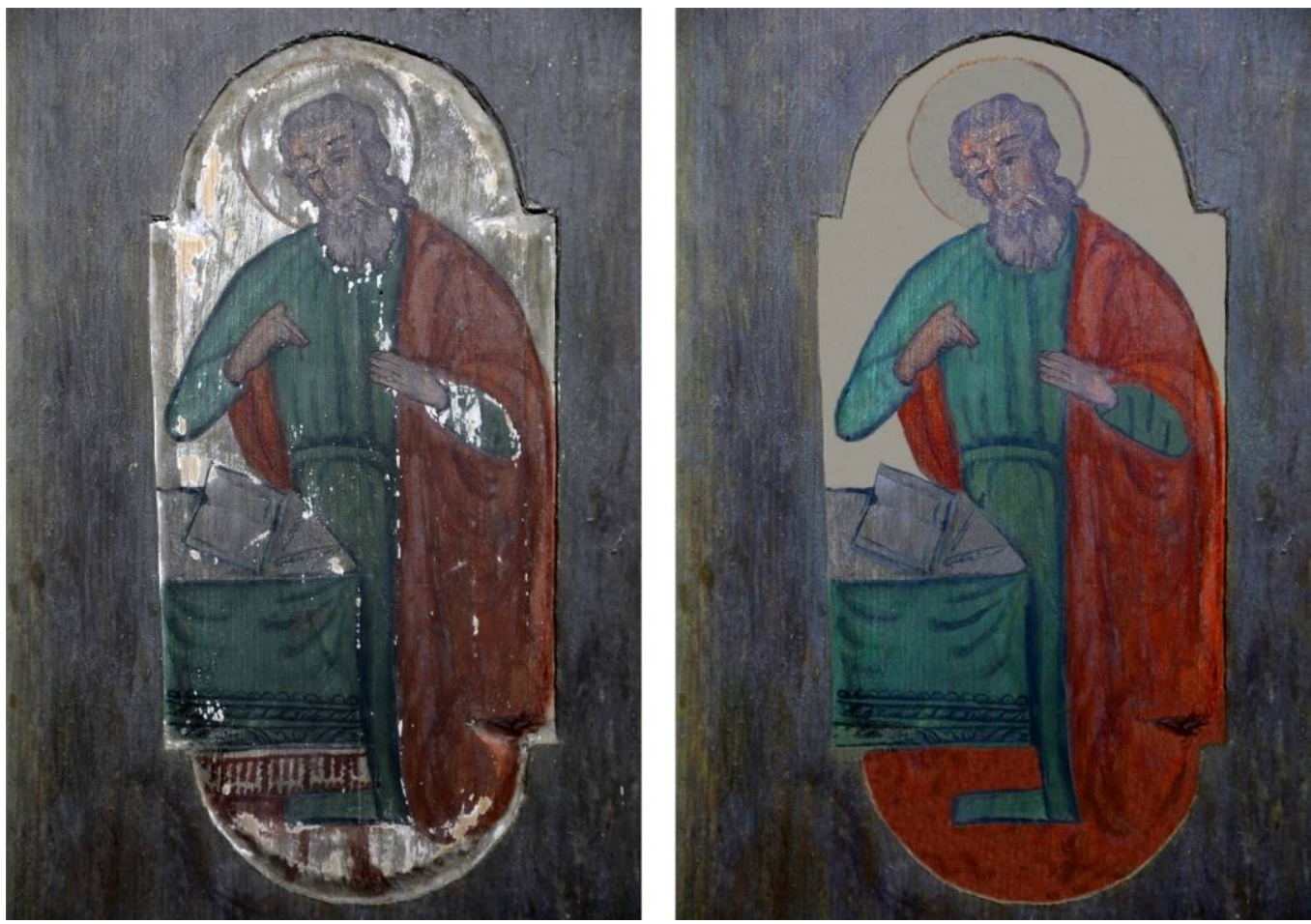

Figure 16. Proposed digital restoration of Saint Marc illustration on the imperial gates from Voivodeni.

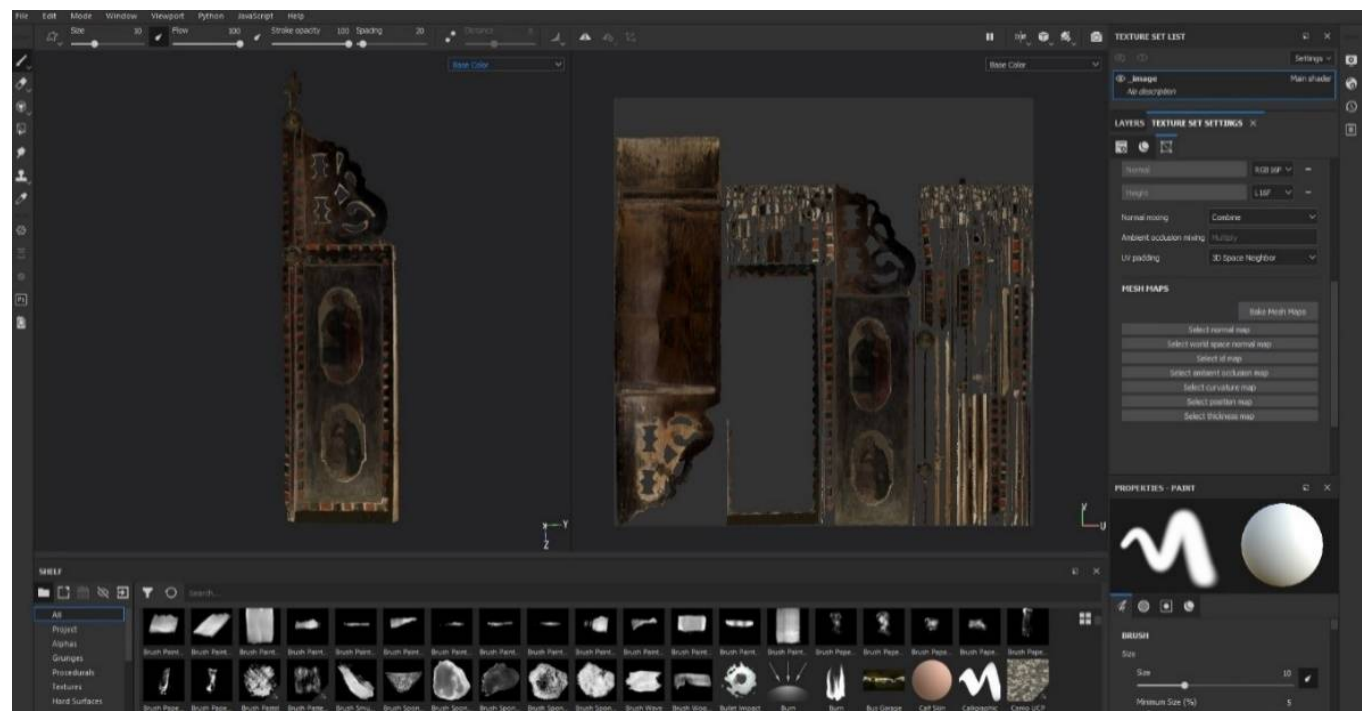

Figure 17. The recolored model of the right-side door of the imperial gates from Voivodeni.

The resulting 3D models of the imperial gates from Voivodeni have been included in a virtual reality application, which is dedicated to the imperial gates from Transylvania (Cluj and Sălaj counties, Romania). The VR application integrates multiple 3D scanned imperial gates and the application has been constantly updated with new scans. An older version of the application has been presented in an article focused on the multidisciplinary 
investigation of the imperial gate from Sălișca, Cluj county, Romania [15]. The application has been created using the Unity game engine software and it is compatible with a wide variety of head-mounted display (HMD) systems. The widespread adoption and compatibility with multiple VR systems have defined Unity as one of the most popular software solutions used to promote digital cultural heritage assets. The main advantage of transferring the 3D scanned model to virtual reality environments in comparison to other dissemination branches, such as webpage, is the ability to create interactive applications using a wide variety of sensors and controllers to manipulate or interact with the digital environment and allow users to fully immerse themselves (as showcased in this video: https:/ /youtu.be/nnWSUrcDdZU---published: 8 March 2021; accessed: 9 March 2021).

For the promotion of the imperial gates, the virtual reality application was designed to work with HTC Vive/Cosmos and Valve Index virtual reality systems (HMD). The software behind the virtual reality tracking and interaction is based on SteamVR Software Development Kit (SDK) and it can work with various configurations-with HTC Vive wireless system up to Cosmos Elite-which does not require base to track the user's "virtual hands" as controllers.

The proposed virtual reality application integrates multiple imperial gates, which are paired with various metadata. On the walls behind each imperial gate, there are images and text metadata regarding the individual location. For some wooden churches, there are also videos that present the location of the wooden church and details regarding the 3D digitization of it.

The audio metadata files are positioned using a location bounding box; therefore, the user will be able to hear additional information regarding each individual wooden church and imperial gate, if he will be in the close proximity of those elements within the virtual environment. The figure below presents the location of the imperial gates from Voivodeni within the virtual environment. As can be observed, the left side of the imperial gates are the original models, as they have been obtained using 3D scanning, while for the ones in the right side, the digital reconstruction of Saint Marc is projected on top of the 3D scanned model, highlighting the difference between the original saturated colors of the painting and the current state.

Unfortunately, for the imperial gates from Voivodeni, they have not been physically curated and repainted, but hopefully there will be funding for this process as well as the whole painting from the interior of the church. Until then, the process of creating digital restoration is being used to raise awareness and to highlight the importance of restoring these types of cultural heritage assets that are present in most villages from Transylvania.

In Figure 18, to the left of the image, the imperial gates from Bulgari, Sălaj County, Romania, are presented, both in their initial state (to the right of the screen) and in their physical restored version (to the left of the screen). Both models have been 3D scanned by the team involved within this project using the same structured light scanner-Creaform Go!SCAN 50.

Another important feature of the virtual environment is based on the ability of the user to navigate the scene using the teleportation function. The system is capable of tracking the user in real time, but there are some limitations regarding the area where the users can move within the real environment, and the feature of teleportation helps to overcome this, easily. Teleportation can allow users to rapidly navigate the scene and to get close to the 3D scanned objects, allowing them to observe the detailed three-dimensional environment.

Using this feature, the users can easily look at the models from the other side and in some cases on the back of the imperial gates there are various elements as, for example, the imperial gates from Sânmihaiu Almașului, Sălaj County, have a text marking on the back, as well as the year 1816 (Figure 19).

The virtual reality application's camera tracking follows the position of the user, by default the camera is set in the middle of the virtual reality environment, where there is a table and three paintings. As soon as the user raises the HMD, the height of the camera will adjust to the user. Some of the imperial gates are above $2 \mathrm{~m}$ height, and some users, such as small children, may encounter problems when they try to spot various details on upper 
side of the gates; therefore, they can use the fly mode with the help of the controllers (by pressing two button-one for up and one for down), which enables them to ascend above the ground floor in the virtual reality environment. At a height of $4 \mathrm{~m}$, there is a collision box, which keeps the user from elevating at a higher distance from the floor, keeping the users within the designated visualization environment.

A short video, illustrating the way in which a user interacts with the objects from the virtual environment, being fully immersed in it using an HMD, can be found at the following link: https://youtu.be/nnWSUrcDdZU (published: 8 March 2021; accessed: 9 March 2021).

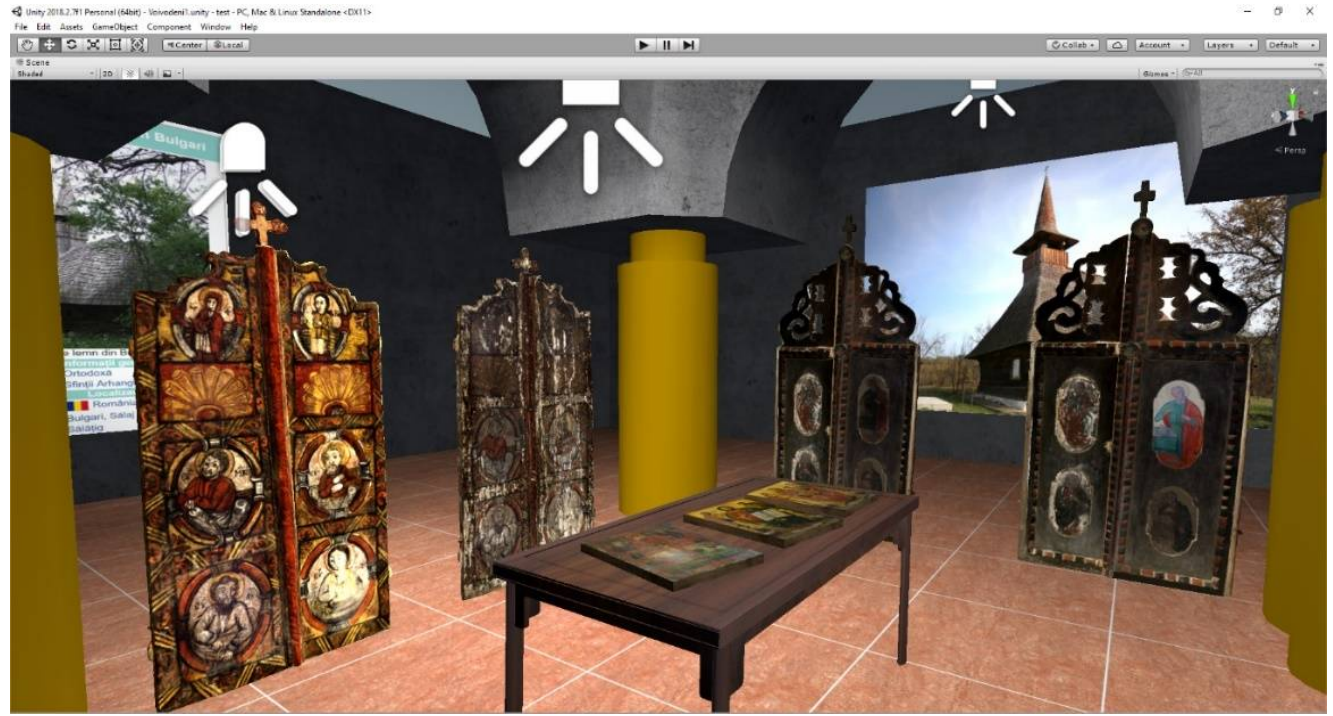

Figure 18. The imperial gates from Voivodeni positioned within the virtual reality environment.

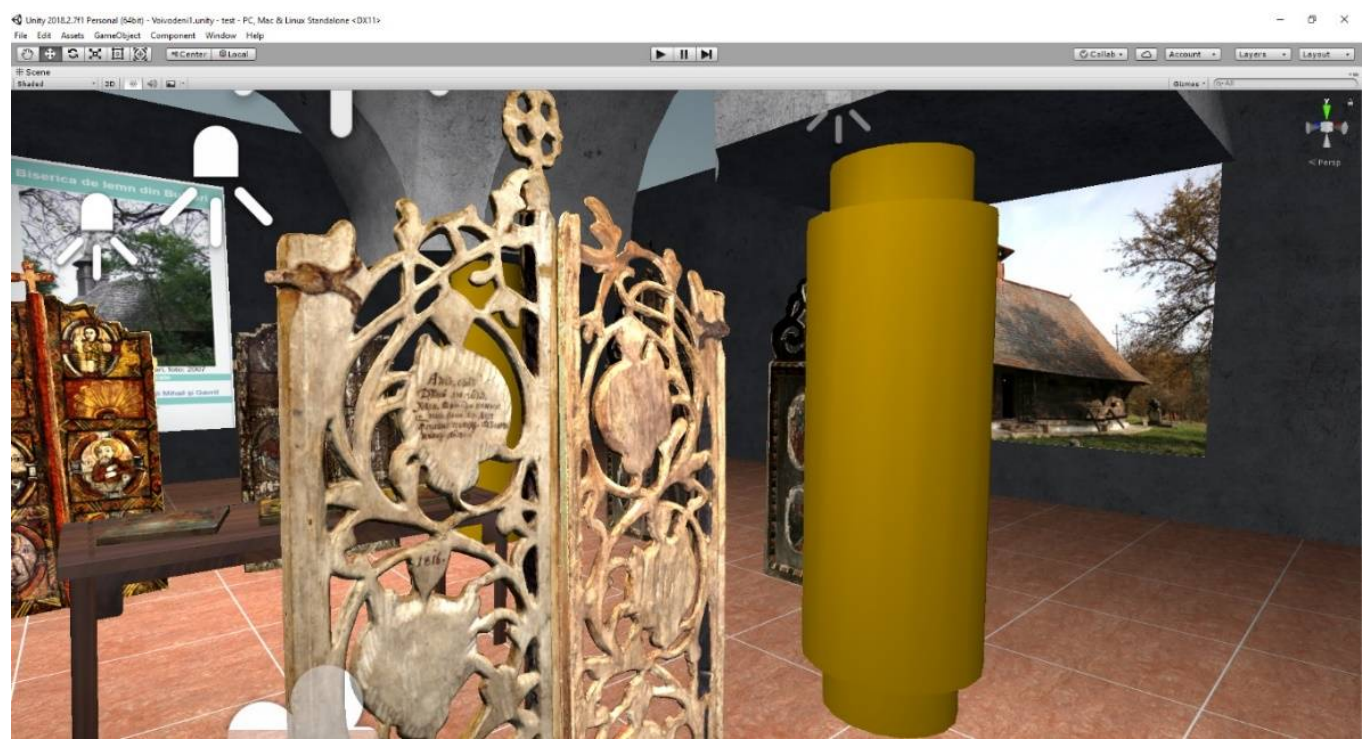

Figure 19. The imperial gates from Sânmihaiu Almașului, Sălaj County, back details.

\section{Conclusions}

Using an interdisciplinary approach, based on physico-chemical analysis and 3D digitization techniques, long-term digital preservation is possible with an information package, which provides an overview and accurate data about the imperial gates. After identifying and documenting the heritage asset, the interdisciplinary team carried out a massive in-situ data collection, which includes physico-chemical analyzes for each color 
(performed in different sampling places), 3D digitization of the monument and of the imperial gates, and artistic and historical documentation.

The physico-chemical analyzes revealed that the woods used to craft the imperial gates and their frame are spruce fir and the component materials used in the painting process are ground gypsum; binder-egg yolk; red painting material--red iron, red lead, red mercury; yellow—orpiment; green—malachite; blue—azurite; white—lead white; egg yolk painting technique.

All of these results can further be used in the restoration of the entire monument and, at the same time, they are digitally preserved and stored together with all of the artistic and historical information, with the 3D model of the church and of the imperial gates, in their current state.

The digital restoration of the imperial gates can be carried out using the pigments identified by the physico-chemical analyzes, applied on the 3D model of the church and the imperial gates. The later ones can be repainted with their current colors (painted layer I) or with the initial colors (from their pristine state), obtained by synthesizing them in the laboratory, based on the pigments identified in the painted layer (painted layer II).

The 3D models can be used in virtual reality applications, which allow access to a much larger number of potential stakeholders, than in-situ visiting, and in the particular case of the imperial gates, allows the general public to see also the backside of the gates, which within the church is forbidden to female persons. Increasing the number of users who can examine the models and interact with them, the "appetite" of visitors for such cultural assets can be stimulated; thus, their reintroduction into the cultural and religious tourist circuits can be achieved.

Finally, it is worth mentioning that the methodology presented in this paper was validated by the authors on five different imperial gates, with various particularities (such as the sculpting complexity-Figure 19-or with multiple painting layers-) being presented in the developed VR application (its fundamentals and practicalities were detailed in the previous section).

Author Contributions: Conceptualization, C.N., I.B., C.M. and D.P.; methodology, C.N., D.P., R.C., Ș.B. and Z.B.; software, V.C.M., O.F.N., R.C., S.B., D.P. and Z.B.; validation, C.N., V.C.M. and O.F.N.; formal analysis, V.C.M., O.F.N., R.C., S.B., D.P. and Z.B.; investigation, V.C.M. and O.F.N.; resources, C.N., D.P., R.C. and S.B.; data curation, V.C.M. and O.F.N.; writing—original draft preparation, C.N., V.C.M., S.B. and R.C.; writing-review and editing, C.N., S.B. and R.C.; visualization, C.N., R.C., S..B. and Z.B.; supervision, C.N., I.B., C.M. and D.P.; project administration, C.N., I.B., C.M. and D.P.; funding acquisition, C.N. and D.P. All authors have read and agreed to the published version of the manuscript.

Funding: This work was supported by a grant from the Romanian Ministry of Research and Innovation, CCCDI-UEFISCDI, project number PN-III-P1-1.2-PCCDI-2017-0812/53PCCDI, within PNCDI III.

Institutional Review Board Statement: Not applicable.

Informed Consent Statement: Not applicable.

Data Availability Statement: Not applicable.

Conflicts of Interest: The authors declare no conflict of interest.

\section{References}

1. Rossato, L.; Massai, P.; Maietti, F.; Balzani, M. Digital Tools for Documentation and Analysis of Vernacular Cultural Heritage in Indian City Centers. Int. J. Archit. Herit. 2019. [CrossRef]

2. García-Molina, D.F.; González-Merino, R.; Rodero-Pérez, J.; Carrasco-Hurtado, B. 3D Documentation for the Conservation of Historical Heritage: The Castle of Priego de Córdoba (Spain). Virtual Archaeol. Rev. 2020, 12, 115-130. [CrossRef]

3. Peng, F.; Ge-Le, T.; Jing, L.; Jia-Xin, L.; Yu-Hu, L.; Hong, Y. Investigation of Ancient Architectural Painting from the Taidong Tomb in the Western Qing Tombs, Hebei, China. Coatings 2020, 10, 688. [CrossRef]

4. Mironova, A.; Robache, F.; Deltombe, R.; Guibert, R.; Nys, L.; Bigerelle, M. Digital Cultural Heritage Preservation in Art Painting: A Surface Roughness Approach to the Brush Strokes. Sensors 2020, 20, 6269. [CrossRef] 
5. Cristache-Panait, I. Biserica Sf. Arhangheli Mihail și Gavril din Voivodeni. Monumente istorice bisericești din Eparhia Ortodoxă Română a Oradei. Biserici de lemn; The Romanian Orthodox Episcopy of Oradea: Oradea, Romania, 1978; pp. $430-432$.

6. Cristache-Panait, I. Bisericile de lemn din Sălaj. Buletinul Monumentelor Istorice 1971, 1, 31-40.

7. Ghergariu, L. Biserici de lemn din Sălaj; MSS in National Archives of Zalău, Personal Collection of Ghergariu Leontin, act 11 of 1976; National Archives of Zalău: Zalău, Romania, 1976.

8. Măruțoiu, C.; Popescu, D.; Bratu, I.; Moraru, R.; Postolache, D.L. Biserici de lemn din Transilvania; Mega: Cluj-Napoca, Romania, 2017; ISBN 978-606-543-857-6.

9. Drăguț, V. Dicţionar Enciclopedic de Artă Medievală Românească; Editura Științifică și Enciclopedică: Bucharest, Romania, 1976; pp. 35-36.

10. Nemes, O.F.; Bratu, I.; Măruțoiu, C.; Postolache, D.L.; Dragomir, M.; Tănăselia, C.; Garabagiu, S. Scientific Investigations of the Imparial Gates from Petrindu Wooden Church, Sălaj County, Romania. X-ray Spectrom. 2018, 47, 176-185.

11. Măruțoiu, C.; Bratu, I.; Nemeș, O.F.; Dit, I.-I.; Comes, R.; Tănăselia, C.; Fălămaș, A.; Miclăus, M.; Marutoiu, V.C.; Moraru, R. Instrumental Analysis of Materials and Topology of the Imperial Gates Belonging to the Apahida Wooden Church, Cluj County. Vibr. Spectrosc. 2017, 89, 131-136. [CrossRef]

12. Bratu, I.; Siluan, M.; Măruțoiu, C.; Kacso, I.; Garabagiu, S.; Măruțoiu, V.C.; Tănăselia, C.; Popescu, D.; Postolache, D.L.; Pop, D. Science Applied for the Investigation of Imperial Gate from Eighteenth Century Wooden Church of Nicula Monastery. J. Spectrosc. 2017. [CrossRef]

13. Moldovan, Z.; Bratu, I.; Măruțoiu, C.; Kacso, I.; Trosan, L.; Pop, D.; Nemes, O.F.; Tănăselia, C. Characterization of an EighteenthCentury Wooden Icon from the Ethnographic Museum of Transylvania. Anal. Lett. 2016, 49, 2597-2605. [CrossRef]

14. Hernanz, A.; Bratu, I.; Măruțoiu, O.F.; Măruțoiu, C.; Gavira-Vallejo, J.M.; Edwards, H.G.M. Micro-Raman Spectroscopic Investigation of External Paintings from St. Dumitru's Church, Suceava, Romania. Anal. Bioanal. Chem. 2008, 392, 263-268. [CrossRef] [PubMed]

15. Neamțu, C.; Măruțoiu, V.C.; Bratu, I.; Măruțoiu, O.F.; Măruțoiu, C.; Chirilă, I.; Dragomir, M.; Popescu, D. Multidisciplinary Investigation of the Imperial Gates Belonging to the 17th Century Wooden Church of Sălișca, Cluj County, Romania. Sustainability 2018, 10, 1503. [CrossRef]

16. Gomes, L.; Bellon, O.R.P.; Silva, P. 3D reconstruction methods for digital preservation of cultural heritage: A survey. Pattern Recognit. Lett. 2014, 50, 3-14. [CrossRef]

17. Măruțoiu, C.; Bratu, I.; Nemeș, O.; Nemeș, D.; Neamțu, C.; Moldovan, Z.; Tia, T.; Udrea, I.; Tigae, C. Scientific investigation of the paintings from the Agârbiciu (Cluj County) Wooden Church. J. Min. Mat. Charact. Eng. 2020, 8, 177-196. [CrossRef]

18. Zamboni, C.B.; Redígolo, M.M.; Miura, V.T.; Costa, I.; Nagai, M.L.E.; Salvador, P.A.V.; Nogueira da Silva, D.G. Non-Destructive Analysis in the Study of Historical Photographs by pXRF and ATR-FTIR spectroscopies. J. Forensic Sci. 2021. [CrossRef]

19. Molari, R.; Appoloni, C.R.; Hennen Rodriguez, S. Non-Destructive Portable X-ray Fluorescence Analysis of the Portrait of a Young Man with a Golden Chain (c. 1635) by Rembrandt and/or Atelier. Appl. Radiat. Isot. 2020, 165. [CrossRef]

20. Hennen Rodriguez, S.; Appoloni, C.R.; Campos, P.H.O.V.; Gonçalves, B.; Kajiya, E.A.M.; Molari, R.; Rizzutto, M.A.; Winter, C. Non-Destructive and Portable Analyses Helping the Study and Conservation of a Saraceni Copper Plate Painting in the São Paulo Museum of Art. Microchem. J. 2020, 155. [CrossRef]

21. Retko, K.; Legan, L.; Ropret, P. SERS Procedure Using Photoreduced Substrates and Reflection FTIR Spectroscopy for the Study of Natural Organic Colourants. J. Raman Spectrosc. 2021, 52, 130-144. [CrossRef]

22. Neamțu, C.; Popescu, D.; Mateescu, R.; Suciu, L.; Hurgoiu, D. About Quality and Properties of Digital Artifacts. Mediterr. Archaeol. Archaeom. 2014, 14, 55-64.

23. Hatzopoulos, J.N.; Stefanakis, D.; Georgopoulos, A.; Tapinaki, S.; Pantelis, V.; Liritzis, I. Use of Various Surveying Technologies to 3D Digital Mapping and Modelling of Cultural Heritage Structures for Maintenance and Restoration Purposes: The Tholos in Delphi, Greece. Mediterr. Archaeol. Archaeom. 2017, 17, 311-336. [CrossRef]

24. Comes, R.; Tompa, V.; Bodi, Ș.; Neamțu, C.; Torok, K.F. From Theory to Practice: Digital Reconstruction and Virtual Reality in Archaeology. J. Anc. Hist. Arch. 2018, 4, 80-88. [CrossRef]

25. Jamhawi, M.; Alshawabkeh, Y.; Freewan, A.; Al-Gharaibeh, R. Combined Laser Scanner and Dense Stereo Matching Techniques for 3D Modelling of Heritage Sites: Dar Es-Saraya Museum. Mediterr. Archaeol. Archaeom. 2016, 16, 185-192. [CrossRef]

26. Lopez-Menchero, V.M.; Grande, A. The Principles of the Seville Charter. In Proceedings of the XXIInd CIPA Symposium, Prague, Czech Republic, 12-16 September 2011.

27. Xu, J.; Ding, L.; Love, P.E.D. Digital Reproduction of Historical Building Ornamental Components: From 3D Scanning to 3D Printing. Autom. Constr. 2017, 76, 85-96. [CrossRef]

28. Vico, L. Authenticity and Realism: Virtual vs. Physical Restoration. In Authenticity and Cultural Heritage in the Age of 3D Digital Reproductions; Di Giuseppantonio Di Franco, P., Galeazzi, F., Vassallo, V., Eds.; McDonald Institute: Cambridge, UK, 2018; pp. 25-33. [CrossRef]

29. Limoncelli, M. Virtual Hierapolıs. Virtual Archaeology and Restoration Project (2007-2015), Hierapolis di Frigia XIII; Ege Yayinlari: Istanbul, Turkey, 2019; ISBN 978-605-7673-10-7. 